\title{
DEVELOPMENT OF DIGESTIVE TRACT OF INDONESIAN SHORTFIN EEL (ANGUILLA BICOLOR BICOLOR)
}

\author{
Murtini Sri ${ }^{*}$, Fisheries Science Lecturer \\ University of Bina Insan Lubuk Linggau, Indonesia \\ Affandi Ridwan, Water Resource Management Lecturer \\ FPIK, IPB, Indonesia \\ Nurhidayat, Physiology and Pharmacology Lecturer \\ $\mathrm{FKH}$, IPB, Indonesia \\ *E-mail: murtinisri296@gmail.com
}

\begin{abstract}
Information on the development of the digestive organs of Indonesian shortfin eel is very much needed in the management of feeding in the breeding of Indonesian shortfin eel's seed activities. This research aimed to examine the development of the structure of the digestive tract of Indonesian shortfin eel macroscopically and microscopically. Indonesian shortfin eel's samples were obtained from Muara Sungai Cimandiri of Pelabuhan Ratu, West Java, by using histochemical method. This fish has digestive organs consisting of the esophagus, stomach, pyloric and intestine. Histologically, the digestive organs consist of four layers, namely mucosal tunica, submucosal tunica, muscularis tunica, and serous tunica. In the Indonesian shortfin eel's esophagus, the mucosal surface has goblet cells, with interlocking lamina propria. Indonesian shortfin eel's stomach is cone-shaped, with a closed and shrinking apex, while the enlarged basal part has an esophageal interface. The intestine has a villous structure with an orderly arrangement with many goblet cells in it. The frontal mucosa has a relatively long villi. The Indonesian shortfin eel's digestive tract plays a role in the process of absorption of food and nutrients for growth, and has a relatively short organ size. Therefore, these fish are grouped into carnivorous fish.
\end{abstract}

\section{KEY WORDS}

Development, structure, Indonesian shortfin eel, digestive tract.

Indonesian shortfin eel (Anguilla bicolor bicolor) is a catadromus fish which is a fish that during its growing period lives in fresh waters, and migrates to the sea for spawning. The Anguilla genus consists of 18 species spread throughout the world, with several phases of the life cycle, namely leptocephali, glass eel, elver, yellow eel, and silver eel. This fish has relatively long developmental phases compared to other fish (Aoyama 2009).

Food becomes a source of nutrition for fish to be able to maintain its life. Indonesian shortfin eel will eat what they find in the waters, and will select foods that fit the size of their mouth openings. The main food of the Anguilla genus consists of benthic organisms, insect larvae, mollusks, and small fish (Machut 2006; Chino and Arai 2010). The type of food consumed by Indonesian shortfin eel changes along with its growth stage, but the type of Indonesian shortfin eel's food in the glass eel and yellow eel phases is not widely known, therefore it is necessary to do research on the types of natural food in these phases.

Indonesian shortfin eel have a unique digestive tract structure, namely the stomach is relatively small, cone-shaped and in the form of a closed pocket, together with the intestine, it forms letter $Y$ (Tesch 1976). In the abdominal chamber, the fish's stomach is located parallel to the intestine. Indonesian shortfin eel's intestine is relatively short in size, starting from the attachment of the stomach to the rectum. Based on this intestinal size, Indonesian shortfin eel is classified as carnivorous fish, compared to herbivorous fish which have a longer digestive tract size (Raji and Norouzi 2010). 
The types of Indonesian shortfin eel food in each phase of the development of Indonesian shortfin eel's life, closely related to the development of the anatomy of the digestive tract, especially the esophagus, stomach, pyloric, and intestine. The development of the structure of the digestive tract in teleostei fish is functionally related to the texture of the food (Canan et al. 2012). This research aimed to examine the development of the structure of the digestive tract of Indonesian shortfin eel including esophagus, stomach, pyloric, and intestine, from various stages of development associated with the type of food. This research is useful in the development of artificial feeding, for Indonesian shortfin eel's habitat management strategies, related to feed management.

\section{MATERIALS AND METHODS OF RESEARCH}

This research used Indonesian shortfin eel obtained from the catches of fishermen in Muara Sungai Cimandiri, Pelabuhan Ratu, West Java. Indonesian shortfin eel used in this research amounted to 56 fish, divided into seven groups based on its size, namely $6,8,10$, $12,14,16$, and $20 \mathrm{~cm}$, each group amounting to 8 fish. All Indonesian shortfin eel samples from each group were opened in their stomach chambers, and their digestive organs were removed to measure portions of the digestive tract. Then, five samples for each group were preserved in $10 \%$ of formalin for macroscopic observation, while three samples were fixed in $10 \%$ of Neutral Buffered Formalin (BNF) for microscopic observation purposes. The entire digestive tract was measured by a ruler (accuracy: $1 \mathrm{~mm}$ ) including the length of the esophagus, stomach and intestine. For microscopic observations, samples were processed according to the Kiernan (1990) method. Samples that have been fixed, then dehydrated with alcohol solution with multilevel concentrations $(70 \%, 80 \%, 90 \%, 95 \%$ and $100 \%)$. Clearing or purifying the tissue was done by immersing the samples in silol, and infiltration was carried out in liquid paraffin, then the samples were planted in a paraffin block.

Samples were sliced using a rotary microtome with a thickness of $5 \mu \mathrm{m}$. Next, the incision was stained with hematoxylin eosin (HE) staining, to observe a general description of each part of the digestive tract including mucosal tunica, submucosal tunica, muscularis tunica, and serous tunica. In addition, the incision was also stained with Periodic Acid Schiff (PAS) staining to observe carbohydrate content in gastric mucus cells, and Masson trichrome (MT) staining to observe the development of connective tissue. Observation of the staining results was carried out with a light microscope (Nikon ${ }^{\circledR}$ Eclipse E600, and then carried out with a digital microphotography (Canon®) EOS 700D. Anatomical and histological observational data from the digestive tract were analyzed descriptively.

\section{RESULTS OF STUDY}

Morphology of Indonesian shortfin eel. Indonesian shortfin eel has a snake-like body shape, black in the dorsal, and grayish white in the ventral part. This fish is equipped with pectoral fins, dorsal fins, and caudal fins (Figure 1).

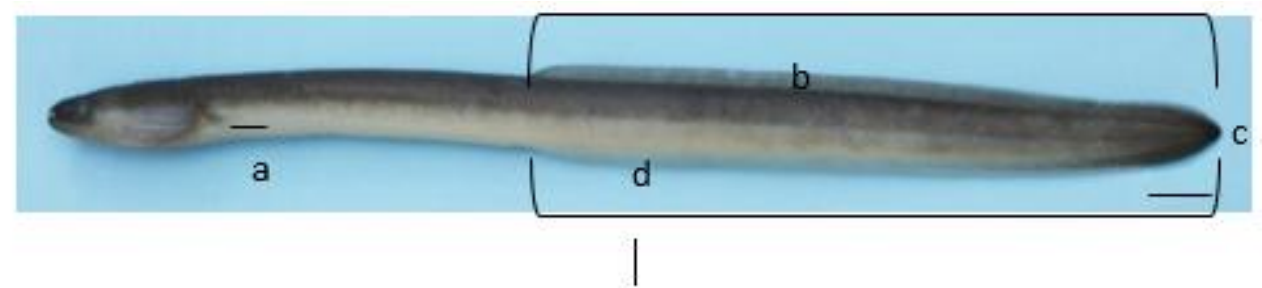

Figure 1 - Body Morphology of Indonesian Shortfin Eel (a. Pectoral Fins, b. Dorsal Fins, c. Caudal Fins, d. Anal fin, Bar $=1 \mathrm{~cm}$ )

The pectoral fins are located right in the caudal operculum to resemble the auricle, while the dorsal and caudal fins fuse along the dorsal of body, tail, and ventral of body. The linea lateralis extends laterally to the body from the caudal operulum to the tail. This animal 
has a relatively pointed mouth shape towards the front, and the corner of its mouth is parallel to the eyeball.

Development of Indonesian Shortfin Eel's Digestive Structure. Indonesian shortfin eel's digestive tract organs consist of esophagus, pyloric, stomach and intestine. This fish has an esophagus shaped like a pipe with a relatively long size. The esophagus is the initial part of the digestive tract which empties directly into the stomach. Indonesian shortfin eel's stomach is cone-shaped, with closed and smaller apex, while the basal part is enlarged and found in the esophageal interface and subsequently associated with the pyloric. Indonesian shortfin eel's pyloric is a relatively short channel, and is located between the stomach and intestine (Figure 2). Indonesian shortfin eel's intestine is relatively short and simple. In general, these organs are divided into three parts, namely the front, middle, and rear intestines. These three parts of the intestine have different diameters.

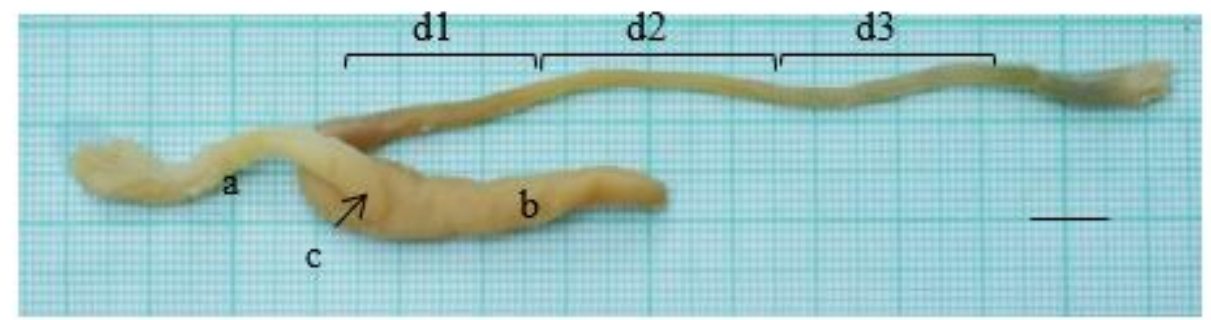

Figure 2 - Morphology of the Digestive Tract of Indonesian Shortfin Eel (a. Esophagus, b. Stomach, c. Pyloric, d1. Front Intestine, d2. Middle Intestine, d3. Rear Intestine. Bar $=1 \mathrm{~cm}$ )

Macroscopic Structure Characteristics of Indonesian Shortfin Eel Digestive Tract. Based on the results of the measurement of the length of Indonesian shortfin eel and esophagus, the regression results obtained were $Y=0.0879 x+0.0914$. An increase of every $1 \mathrm{~cm}$ of body length of Indonesian shortfin eel was followed by an increase in esophageal length of $0.1793 \mathrm{~cm}$. The regression value obtained from the measurement of the stomach length against the fish body length was $Y=0.4579 X+0.0314$. Indonesian shortfin eel's stomach increased by $0.4893 \mathrm{~cm}$ for an increase of every $1 \mathrm{~cm}$ of body length. An increase on the relative length of the stomach was faster than the esophagus, but slower than the increase on body length. Increased stomach length was seen in Indonesian shortfin eel's size of $16 \mathrm{~cm}$ to $20 \mathrm{~cm}$. Different results were obtained from measurements of length of intestine growth with a regression value that nearly doubled by $0.8267 \mathrm{~cm}$, compared with an increase in stomach length, whereas an increase in the length of the intestine of Indonesian shortfin eel from $16 \mathrm{~cm}$ to $20 \mathrm{~cm}$ was relatively fast, such as found in the stomach (Figure 3).

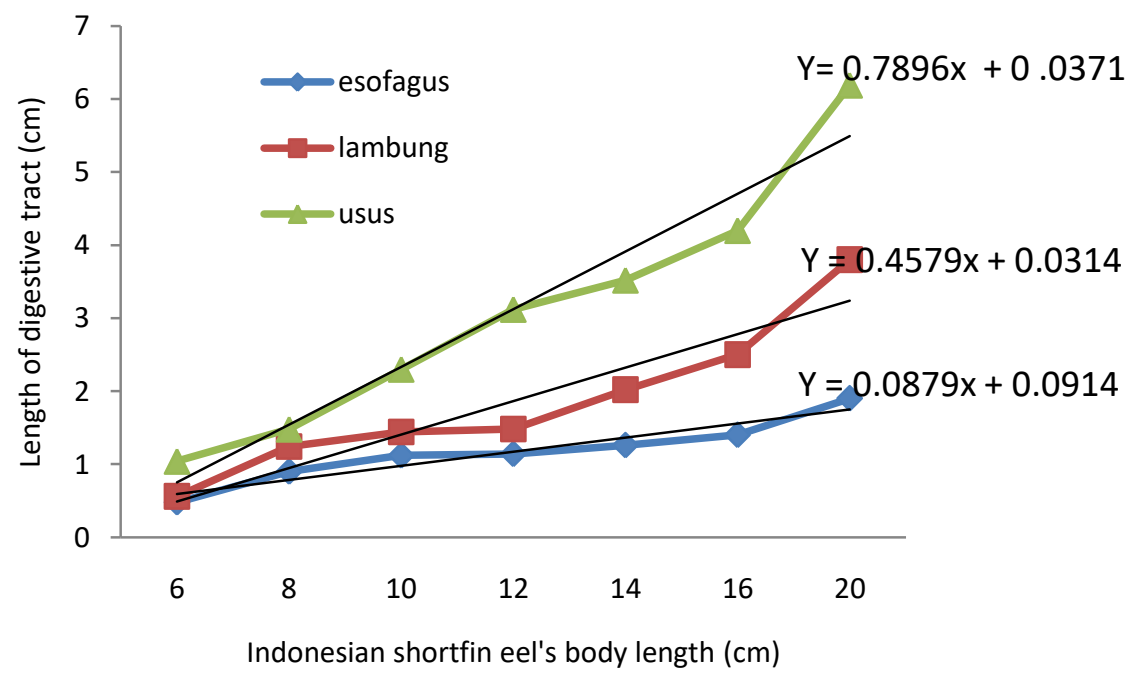

Figure 3 - Comparison of the length of some parts of the digestive tract with Indonesian shortfin eel's body length 
Overview of Microscopic Structure of Digestive Tract. Indonesian shortfin eel's esophagus has mucosa consisting of inline cylindrical epithelium. Among these mucosal cells, many goblet cells are found. In $12 \mathrm{~cm}$ Indonesian shortfin eel, the lining of the esophageal mucosa is composed predominantly by cylindrical goblet cells with a relatively small size. In $20 \mathrm{~cm}$ eel, the mucosal layer is covered with larger goblet cells, with inline cylindrical flat epithelial cells, relatively large in size and almost covering the entire esophageal mucosal layer (Figure 4).

The lamina propria of esophagus of Indonesian shortfin eel consists of loose connective tissue and fat tissue. Loose connective tissue is found in the mucosa of $20 \mathrm{~cm}$ Indonesian shortfin eel, whereas in smaller fish, this layer is not found. In the profundal tunica mucosa, there is lamina propria and tunucosa submucosa. In both layers, loose connective tissue and blood reed are found. The esophageal submucosal tunica of $12 \mathrm{~cm}$ fish consists of a relatively small amount of loose connective tissue and blood vessels, whereas in longer fishes, this layer thickens with increasing fish length. Tunic muscularis of Indonesian shortfin eel is located in the superficial tunica submucosa, and consists of two layers of muscle, namely the circular (internal) muscle, and the longitudinal (external) muscle. Circular muscles surround the esophagus continuously, whereas longitudinal muscles have several bundles of muscles in the superficial circular muscle. In $12 \mathrm{~cm}$ fish, a relatively thin layer of circular and longitudinal muscle is found, whereas $20 \mathrm{~cm}$ fish have a relatively thick circular muscle with several bundles of longitudinal muscles at its superficial part. In the outer layer of the esophagus, there is a serous tunica that lines the entire outer surface of the esophagus (Figure 4).

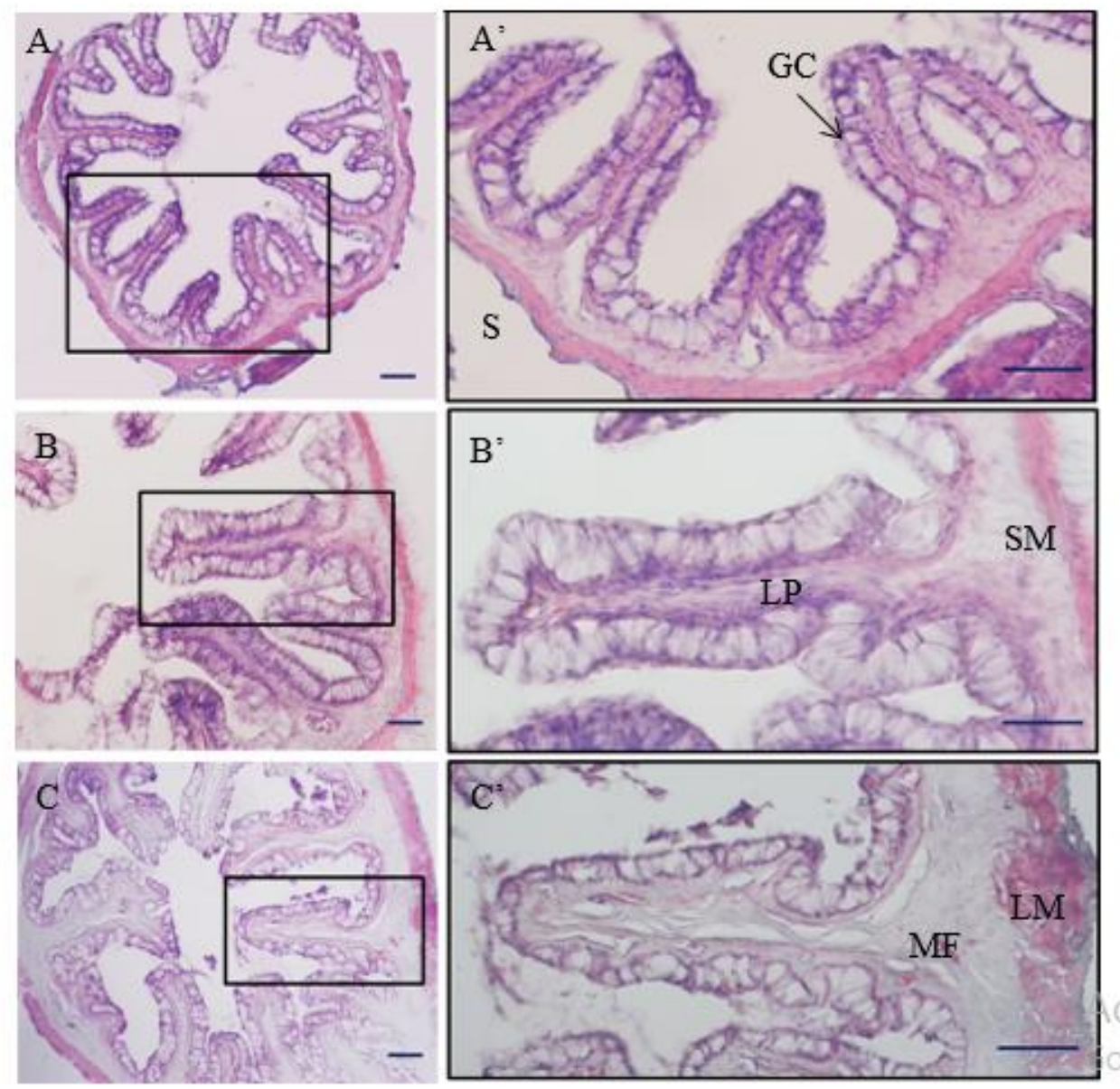

Figure 4 - Microscopic picture of Indonesian shortfin eel's cross section. A: $12 \mathrm{~cm}$ Indonesian shortfin eel, A' inset (A), B: $16 \mathrm{~cm}$ Indonesian shortfin eel, B' inset (B), C: $20 \mathrm{~cm}$ Indonesian shortfin eel, C' inset (C) GC: Goblet cell, LP: Lamina propria, LM: Lamina muscularis, SM: Submucosa, S: Serosa, MF: Mucosa Fold, HE staining. Bar of A, B, C $=200 \mu \mathrm{m}, A^{\prime} B^{\prime} C^{\prime}=50 \mu \mathrm{m}$. 


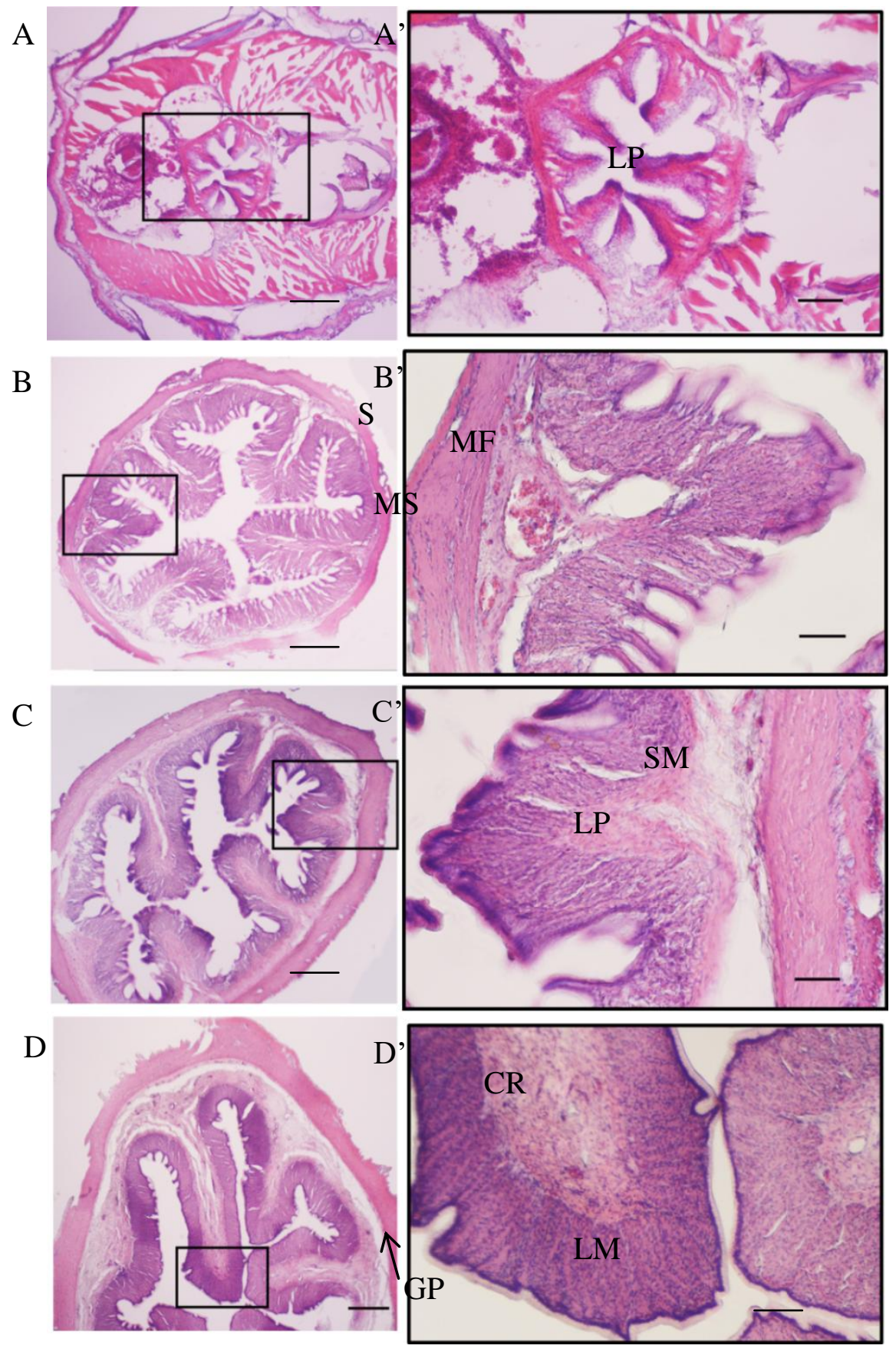

Figure 5 - Microscopic picture of Indonesian shortfin eel's cross section. A: $6 \mathrm{~cm}$ Indonesian shortfin eel, A' inset (A), B: $14 \mathrm{~cm}$ Indonesian shortfin eel, B' inset (B), C: $16 \mathrm{~cm}$ Indonesian shortfin eel, C' inset (C) D: $20 \mathrm{~cm}$ Indonesian shortfin eel, D' inset. GP: Gastric pit, LP: Lamina propria, MF: Mucosa Fold, Sm: Submucosa, S: Serosa. HE staining. Bar of A, B, C, D = $200 \mu \mathrm{m}, A^{\prime} B^{\prime} C^{\prime} D^{\prime}=50 \mu \mathrm{m}$

Indonesian shortfin eel's stomach is cone-shaped, and consists of three parts, namely cardia, fundus, and pylorus. The mucosal tunica of stomach of the Indonesian shortfin eel, which is $6 \mathrm{~cm}$ in size, has layers of up to several layers of epithelium, whereas in $14 \mathrm{~cm}, 16$ $\mathrm{cm}$ and $20 \mathrm{~cm}$ fish, this tunica consists of inline cylindrical epithelium and goblet cells coated by mucus. In $14 \mathrm{~cm}$ and $16 \mathrm{~cm}$ fish, the gastric pit has not formed completely in the mucosa, whereas in $20 \mathrm{~cm}$ fish, the gastric pit has formed completely between the epithelium and the mucus (Figure 5D). In the profundal of mucosal epithelium, there is a matrix of the gastric mucosa. In this section, chief cells and parietal cells are found. In $14 \mathrm{~cm}$ fish, chief cells are found to be few in number and relatively small in size, whereas in $16 \mathrm{~cm}$ and $20 \mathrm{~cm}$ fish, the number of chief cells is higher and larger in size with a relatively large nucleus in the middle 
of the cell. In $14 \mathrm{~cm}$ fish, a small amount of parietal cells is found, whereas in $16 \mathrm{~cm}$ and 20 $\mathrm{cm}$ fish, the number of parietal cells is higher and it is spread throughout the gastric mucosa (Figure $6 \mathrm{~A}^{\prime}$ ).

In the tunica of the gastric mucosa, the cardia gland is found (Figure 5D'). The lamina propria in the stomach of Indonesian shortfin eel has loose connective tissue. This tissue is found in $14 \mathrm{~cm}, 16 \mathrm{~cm}$ and $20 \mathrm{~cm}$ fish. In the submucosal tunica of the stomach, loose connective tissue and blood reed are found, this layer gets thicker as the Indonesian shortfin eel get older. In $14 \mathrm{~cm}$ fish, blood reeds are more dominant in the mucous villous profundal, whereas in larger fish, blood reed size is greater and its distribution is evenly distributed among submucosal connective tissue. In general, the gastric muscularis tunica is similar to the esophagus, this layer consists of two layers of muscle namely the longitudinal (external) and circular (internal) muscle layer. In $6 \mathrm{~cm}$ fish, gastric muscle is still very simple and cannot be distinguished between circular and longitudinal muscles, whereas in $14 \mathrm{~cm}$ fish, in size have thicker circular muscles compared to longitudinal muscles. Epithelium cells of the gastric mucosa are positively colored by PAS staining (Figure 7).
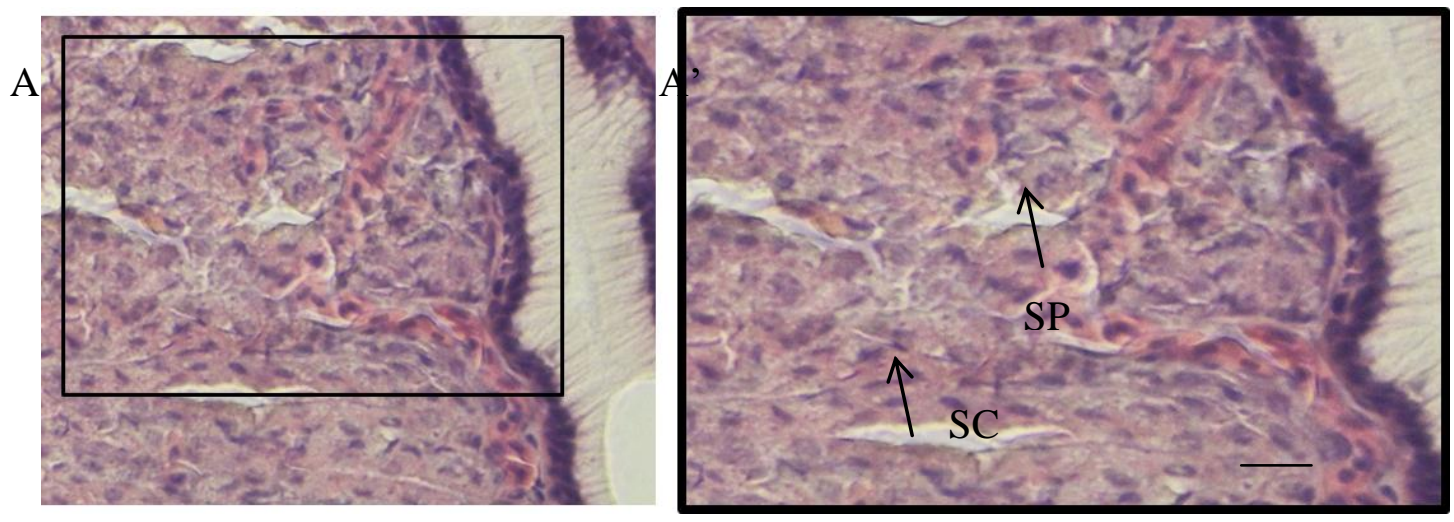

Figure 6 - Mucosal and submucosal appearance of the Indonesian shortfin eel's stomach. SP: Parietal cells, SC: Chief cell, HE staining, Bar of $A=200 \mu \mathrm{m}$ and $B=50 \mu \mathrm{m}$

A

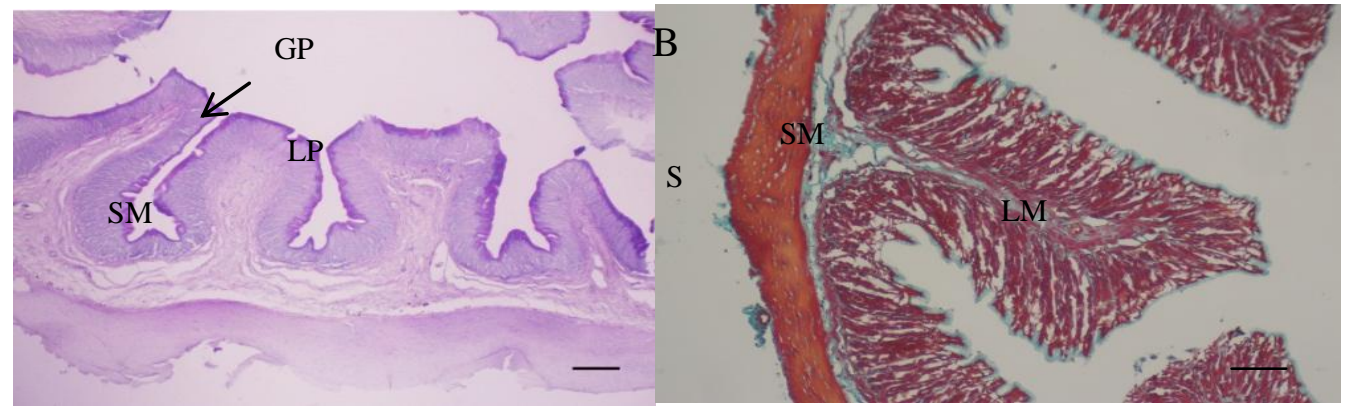

Figure 7 - Picture of cross section of the Indonesian shortfin eel's stomach which is colored by PAS (A) and Masson trichrome (B) staining. GP: Gastric pit, LP: Lamina propria, SM: Submucosa, LM: Lamina muscularis, LM: Lamina mucosa, S: Serosa, Bar of $A, B=200 \mu \mathrm{m}$

The pyloric is the border between the stomach and intestine. The pyloric of Indonesian shortfin eel have mucous tunica with villi, each villi branching several microvilli. Indonesian shortfin eel that are 8 to $20 \mathrm{~cm}$ in size have a relatively similar villi shape, but the villi size increases and the shape is more complex in larger fish. In the tunica mucosa from the pyloric, the digestive glands are not found. The muscularis tunic in the pyloric is relatively thick, formed by two layers of muscle, with a very thick circular muscle (Figure 7). 


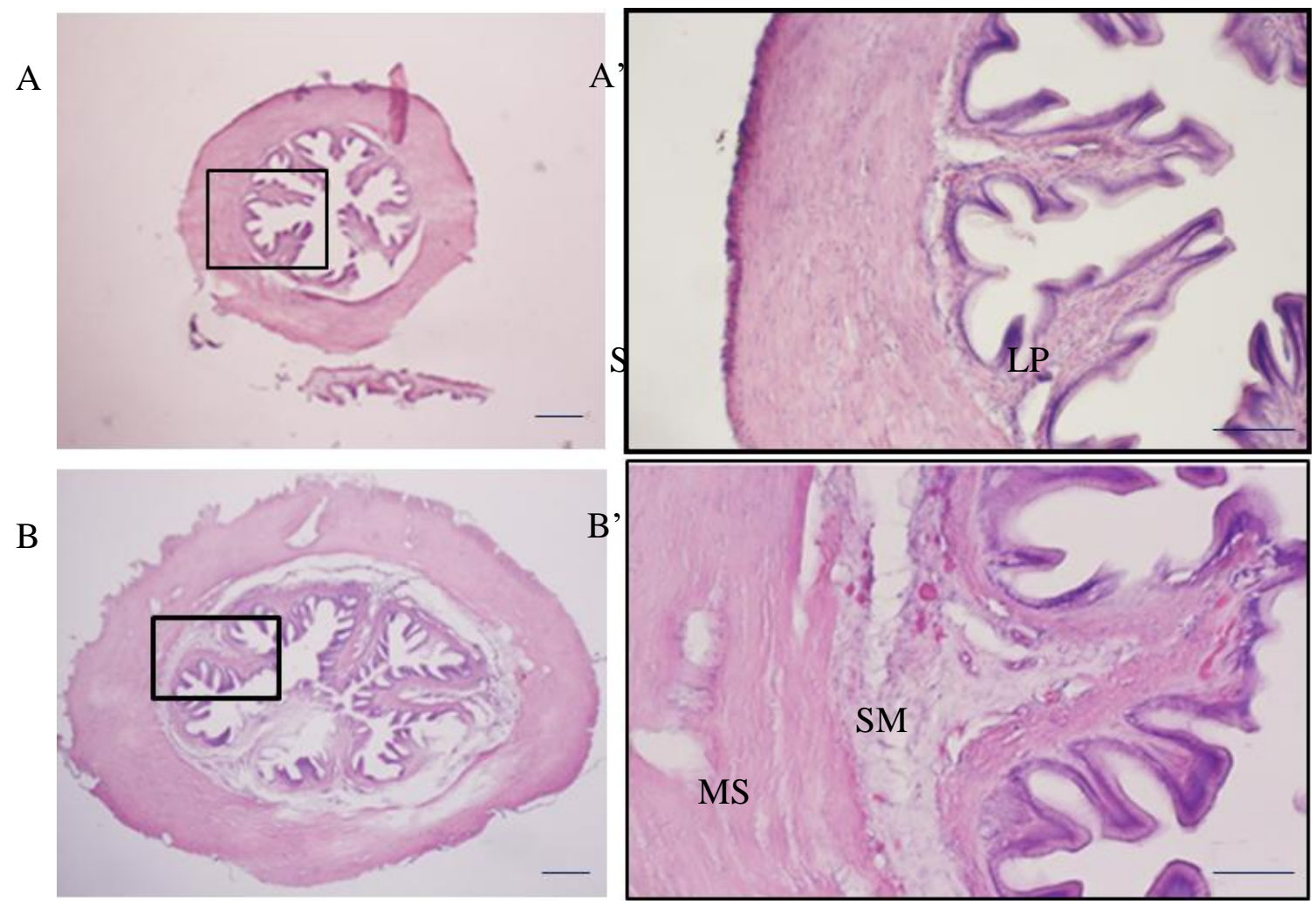

Figure 7 - Histological picture of Indonesian shortfin eel, A: $8 \mathrm{~cm}$ Indonesian shortfin eel, B: $20 \mathrm{~cm}$ Indonesian shortfin eel, $A^{\prime}$ inset (A), B' inset (B), S: Serosa, LM: Lamina muscularis, SM: Submucosa, LP: Lamina propria. HE staining. Bar of $A, B=200 \mu \mathrm{m}$ and $A^{\prime} B^{\prime}=50 \mu \mathrm{m}$.

The intestine is the longest part of the digestive tract of the Indonesian shortfin eel. This intestine consists of the front intestine, middle intestine, and rear intestine. In tunica intestinal mucosa, there are protrudes covered by inline cylindrical epithelial cells, among these epithelial cells, many goblet cells are found (Figure 8 ). In $8 \mathrm{~cm}$ fish, mucous villi have a simple shape, the size of the villi is relatively short, with a relatively small number of goblet cells. $16 \mathrm{~cm}$ fish have villi with a simple structure but are relatively long in size, and the number of goblet cells appear to be higher, and are larger in size. In $20 \mathrm{~cm}$ fish, villi size increases in length and it has higher number, with more complex shapes, with goblet cells found are large and evenly distributed along the intestinal mucosal epithelium (Figure 8).

Lamina propria of Indonesian shortfin eel's intestine is located in the profundal of the mucosal epithelium consisting of loose connective tissue, fat and blood reed. This layer in fish smaller than $16 \mathrm{~cm}$ appears thin in each villi, whereas in Indonesian shortfin eel larger than $16 \mathrm{~cm}$, lamina propria is a thick enough layer with longer mucous villi. In the basal villous mucosa and in the superficial mucosal muscularis, lieberkuhn gland is found, with a lumen shape surrounded by cells that are round in pink and large. This gland is found in fish larger than $16 \mathrm{~cm}$, but not found in fish smaller than that size. Tunica submucosal of Indonesian shortfin eel contains loose connective tissue and blood reed. This layer is also relatively thick in fish larger than $16 \mathrm{~cm}$, and very thin in fish smaller than that size. In general, tunica muscularis and Indonesian shortfin eel's intestine are similar to the stomach, this layer consists of circular (internal) and longitudinal (external) muscles. In $8 \mathrm{~cm}$ fish, cycular and longitudinal muscle is a very thin layer of muscle, whereas in $16 \mathrm{~cm}$ and $20 \mathrm{~cm}$ fish, circular muscle is thicker compared to longitudinal muscle. Serous tunica has connective tissue that encloses the entire superficial surface of the intestine. 


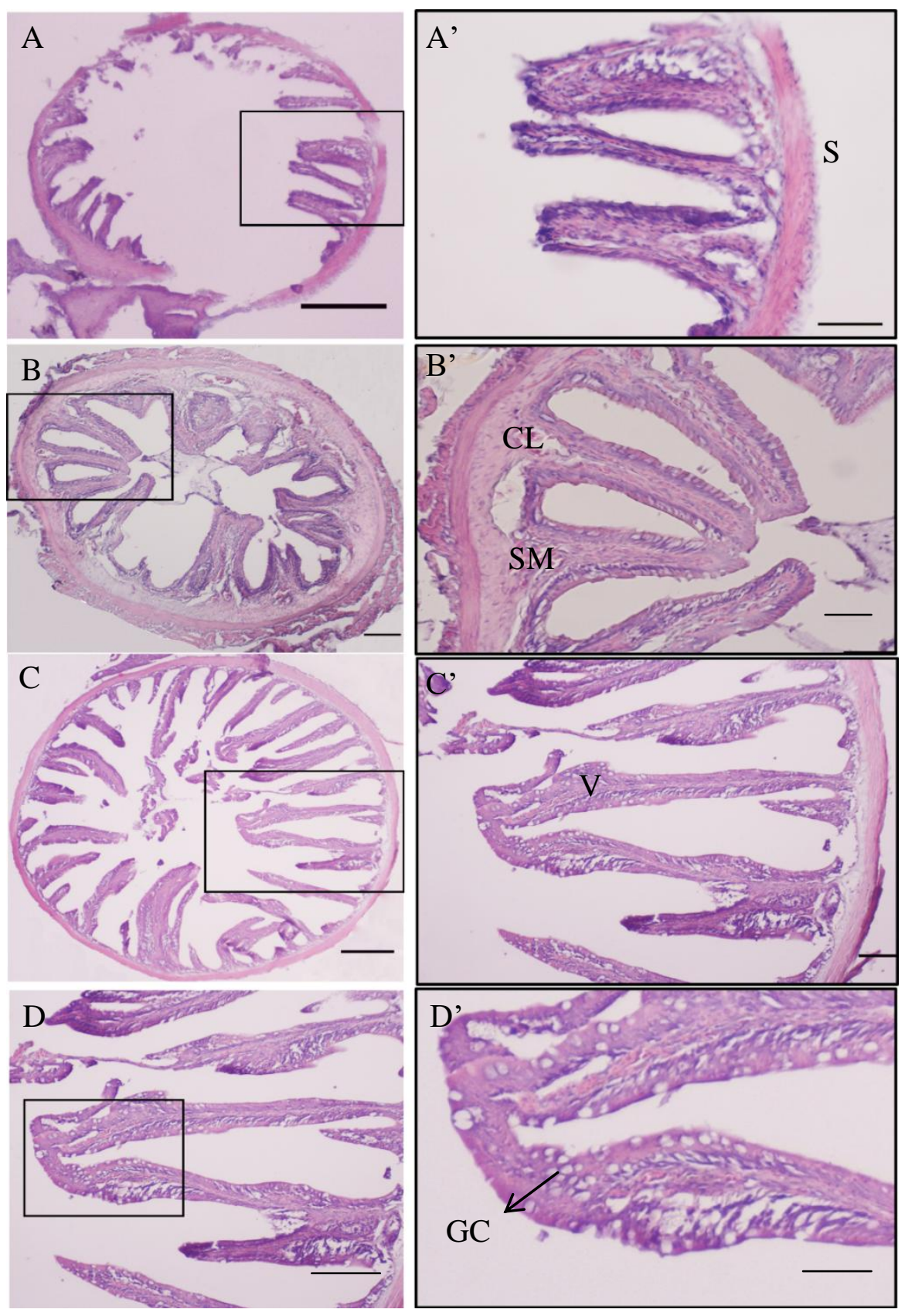

Figure 8 - Microscopic view of Indonesian shortfin eel's cross section. A: $8 \mathrm{~cm}$ Indonesian shortfin eel, B: $16 \mathrm{~cm}$ Indonesian shortfin eel, C: $20 \mathrm{~cm}$ Indonesian shortfin eel, A' insert (A) cross section of the intestine (A) and A'insert (A) B' insert (B), C: insert (C) Serosa (S) Crypt of lieberkuhn (CL), Submucosa (SM), Lamina muscularis (LM), Villus (V) Goblet Cell (GC), HE staining. Bar of A, B, C, D $=200 \mu \mathrm{m}$ and $A^{\prime}, B^{\prime}, C^{\prime}, D^{\prime}=50 \mu \mathrm{m}$

\section{DISCUSSION OF RESULTS}

Indonesian shortfin eel's digestive tract is a channel that functions to digest and absorb food. This channel consists of esophagus, stomach, pyloric and intestine. The esophagus is the initial part of the digestive tract in the form of a pipe that empties directly into the stomach. Indonesian shortfin eel's stomach is cone-shaped, with a relatively short pyloric size between the stomach and intestine. Indonesian shortfin eel's intestine is relatively short and simple compared to other types of carnivorous fish.

The results of measurements of the digestive tract of Indonesian shortfin eel show that the increase in the length of the esophagus during the growth period is relatively slow, this indicates that the role of the esophagus in the digestive process is more dominant as an 
organ that delivers food to the stomach (Awaad et al 2014). Indonesian shortfin eel's stomach grows relatively faster than the esophagus, this is in accordance with the type of food consumed by $6 \mathrm{~cm}$ fish, which is dominated by zooplankton (Murtini et al 2015). Functionally, the increase in fish stomach size is accompanied by an increase in stomach diameter, which is influenced by the type and amount of food consumed (Naguib et al. 2012). A relatively long esophagus is also found in Indonesian shortfin eel (Monopterus albus) (Affandi et al. 2009). Indonesian shortfin eel with a size larger than $16 \mathrm{~cm}$, have consumed food with a more varied size and type in the form of phytoplankton and zooplankton, so that the size of the intestine influences the optimization of food absorption. Intestine length growth in carnivorous fish is influenced by the type and size of the food (Khojasteh 2012).

Indonesian shortfin eel eat food in the waters with the help of the sense of smell. The mouth functions as a place for chemical digestion and then passes on to the esophagus. This organ serves as a way for food to enter the stomach, in the esophageal epithelial layer, there are many goblet cells that produce mucus. The mucus serves to coat the esophageal mucosa so that food easily passes through the esophageal lumen and prevents damage to the esophageal mucosal epithelium when food goes to the stomach (Raji and Norouzi 2010).

In the profundal of lamina propria of the mucous esophagus mucosa, there are lamina propria and tunica submucosa. Between these layers are loose connective tissue and blood vessels. The blood vessels function to vascularize the surrounding tissue and cells (Abdulhadi 2005). Tunica esophageal mucosa from Indonesian shortfin eel has a lot of goblet cells, which serves to facilitate the passage of food into the stomach. This is also found in the structure of the Indonesian shortfin eel's esophagus (Monopterus albus) with a very large number of goblet cells along its epithelium (Dai et al. 2007). Tunica muscularis of Indonesian shortfin eel consists of circular (internal) and longitudinal (external) muscles. Tunica muscularis of Indonesian shortfin eel have thicker muscles than other carnivorous fish, which serves to push food into the stomach (Albrecht 2001). Stomach functions as a place to store food, and digestive processes enzymatically. Indonesian shortfin eel's stomach is coneshaped, consisting of cardia, fundus, and pylorus. The surface of the stomach has five to eight villi. Cardia and fundus have villous sizes that are almost the same length, whereas in the pyloric section, villi are relatively short in size. In general, the mucosa of the three parts of the Indonesian shortfin eel's stomach is lined with inline cylindrical epithelium, between which lighter-colored goblet cells are found in epithelial cells. The surface of the gastric mucosa has relatively long villi, and each Indonesian shortfin eel has microvilli (Osman 1991). The folds on the mucous gastric mucosa serve to expand the digestive area, increasing the efficiency of the digestive process.

Microvilli from the gastric mucosa penetrate the lamina propria to form microscopic grooves that lead to the gastric pit, as the exit from the gastric gland channel, which are formed perfectly between the epithelial cells and the mucus. This mucus functions to protect mucosal epithelial cells from the influence of hydrochloric acid and pepsin enzymes (Petrinec et al. 2005). Chief cells in Indonesian shortfin eel are cuboid-shaped, the cell nucleus is located at the edge, with cytoplasm which is light purple, while parietal cells are oval, the cell nucleus is located in the middle of the pink cytoplasm. This chief cell produces pepsinogen as a proenzyme and becomes active as a pepsin enzyme with the help of hydrochloric acid produced by parietal cells. Furthermore, this pepsin enzyme digests protein molecules into simpler molecules (Abdulhadi 2005).

Gastric muscularis tunica is similar to the esophagus, this layer consists of two layers of muscle namely circular and longitudinal muscle layers. Tunica muscularis of Indonesian shortfin eel's stomach function to help the process of digestion of food in the stomach optimally (Nasruddin et al. 2014). The same thing was found in the Schible mystus carnivorous fish which consisted of tubular and longitudinal muscle layers (Naguib et al 2012).

The pyloric is part of the digestive tract located between the stomach and front intestine, with a relatively small size and narrow. Mucous tunica forms villi, each villi is equipped with microvilli. The circular muscles possessed by the tunica mucosa are very thick. This muscle functions as a spingter muscle to prevent re-entry of food from the 
intestine into the pyloric. Canan et al. (2012) stated that the same condition was found in the pyloric fish of Stegastes fuscus which also did not have glands.

The intestine becomes the longest part of the digestive tract, which has a relatively similar shape and diameter. Indonesian shortfin eel's intestine consists of the front, middle and rear intestines, in the front and middle have a greater number of villi than in the rear intestine. This number determines the digestion process associated with fish eating habits. The instestine of Rainbow trout, and Sparus aurata have long villi to expand the intestinal surface in optimizing the absorption of food nutrients (Khojasteh 2012). Goblet cells found in the intestinal mucosa produce mucus which functions to maintain intestinal epithelial cells. An increase in the length and number of villi in the intestine is in line with an increase in fish size to increase the efficiency of food absorption (Genten et al. 2009).

Natural food consumed by Indonesian shortfin eel consists of phytoplankton, zooplankton, and nekton. The type of food that Indonesian shortfin eel consumed in the glass eel, elver and yellow eel phases is in accordance with the size of the mouth opening, increase in body length, the development of macroscopic and microscopic structures and the function of the digestive tract. Food and nutrient absorption occurs in each organ segment with their respective roles and functions. The type of food which is processed by Indonesian shortfin eel will affect the structure of the macro and microscopic development of the digestive tract. The morphology of the digestive tract of Indonesian shortfin eel macroscopically and microscopically can support their natural eating habits.

\section{CONCLUSION}

The macroscopic structure of Indonesian shortfin eel digestive tract organs develops along with the increase in body length. The relatively large number of goblet cells in the esophagus facilitates the entry of food into the digestive tract. Indonesian shortfin eel stomach which is large and resembles a closed pocket, while regulating the entry and exit of food from the stomach and intestine is regulated by a very thick muscularis muscle in the pyloric part.

\section{REFERENCES}

1. Abdulhadi HA. 2005. Some comparative histological study on alimentary tract of tilapia fish (Tilapia spirulus) and sea bream (Mylio cuvieri). Egyptian J. Aqu. Res. Vol.3, 388 397.

2. Affandi R., Sjafei DS., Rahardjo MF, Sulistiono 2009. Fisiologi ikan, Pencernaan dan Penyerapan Makanan. Departemen Manajemen Sumberdaya Perairan. Fakultas Perikanan dan IImu Kelautan. IPB Press. 240 hal.

3. Albrecht M. 2001 Anatomical features and histology of the digestive tract of two related neotropical omnivorous fishes (Characiformes; Anostomidae). J. Fish Biol. 58, 419-430.

4. Aoyama J. 2009. Life history and Evolution of Migration in Catadromous Eels (Anguilla genus). Ocean Research Institute. The University of Tokyo. 1-42 p.

5. Awaad AS, Moawad UK, Tawfiek MG. 2014. Comparative histomorphological and histochemical studies on the oesophagus of Nila tilapia (Orechromis niloticus and African Cathfish (Clarias gariepinus). J. Histol. 1 - 10.

6. Canan B, do Nascimento WS, da Silva MB, Chellappa S. 2012. Morphohistology of the digestive tract of the damsel fish stegastes fuscus (Osteichthyes: Pomacentridae). Sci Word. J.1-9.

7. Chino N, Arai T. 2010 Habitat use and habitat transitions in the tropical eel Anguilla bicolor. Environ Biol Fish. $89: 571$ - 578.

8. Dai X, Fang W, Shu M. 2007. Histological and ultrastructural study of digesttive tract of rice field eel monopterus albus. J. Appl. Ichthyol. 23:177-183.

9. Genten F, Trewinghe E, and Danguy A. 2009. Digestive System. In Atlas of Histology. Science Publishers. 75-91. 
10. Khojasteh B. 2012. The morphology of the post gastric alimantary canal in teleost fish. Int. J. Aqu. Sci. 3(2):71-88.

11. Kiernan JA.1990. Histological and Histochemical Methods: Theory and Practice. 2 Ed. Oxford (GB) : Pergamon Pr.

12. Machut SL. 2006 Population dynamics, Anguillicola crassus infection, and feeding selectivity of American Eel (Anguilla Rostrata) In Tributaries of the Hudson River, New York. 177p.

13. Murtini S, Affandi R, Nurhidayat. 2015. Makanan alami benih ikan sidat (glass eel) di muara sungai cimandiri Pelabuhan Ratu Sukabumi. J. Oseanologi dan Limnologi Indonesia. (Submitted).

14. Naguib S.A, El-Sabaka H.A, Ashour F. 2012. Comparative histological and ultrastructural studies on the stomach of Schilbe mystus and the intestinal swelling of Labeo niloticus. J. Am Sci.7( 8). 251-263.

15. Nasrudin N.S, Azmal M.N.A, Ismail A. 2014. Histological features of the gastrointestinal tract of wild Indonesian shortfin eel, Anguilla bicolor bicolor (McClelland, 1984) captrured in peninsular Malaysia. J.Sci Word. (1) 1-8

16. Osman AH, Caceci T. 1991. Histology of stomach of Tilapia nilotica (Linnaeus, 1758) from the river Nile. J.Fish Biol. 38: 211-223.

17. Petrinec Z, Nejedli.S, Kuir S, 2005. Mucosubstances of the digestive tract mucosa in northern pike (Esox Lucius L.) and European catfish (Silurus glanis L.). Vet. Archiv., 75 (4) :317-327.

18. Raji A.R. Norouzi E. 2010 Histological and histochemical study on the alimentary canal in walking catfish (Clarias batracus) and Piranha (Serrasalmus nattereri). J. Vet. Res. Shiraz University Vol 11.

19. Tesch SW. 1976. The Eel, Biology and manajement of Anguilid eels. Chapman and Hall. $434 \mathrm{p}$. 